\title{
Hubungan Tingkat Pengetahuan dan Perilaku Masyarakat tentang Covid-19 di Masa Pandemi Covid-19
}

\author{
Relationship between Knowledge Level and Public Behavior about Covid-19 \\ During the Covid-19 Pandemic \\ Siti Hidayati Mukhlis ${ }^{(1)}$, Sikni Retno Karminingtyas ${ }^{(2)}$ \\ (1)(2)Program Studi Farmasi, Fakultas Kesehatan, Universitas Ngudi Waluyo \\ Email : yeatik22@gmail.com
}

\begin{abstract}
ABSTRAK
Covid-19 merupakan penyakit infeksi pernafasan yang disebabkan oleh SARS-CoV-2. Pandemi Covid-19 dianggap sebagai bencana kesehatan global yang paling krusial pada abad ini dan tantangan terbesar yang dihadapi umat manusia sejak Perang Dunia ke-2. Jumlah kasus di Indonesia terus meningkat setiap hari dan mengakibatkan ancaman bagi masyarakat dalam hal kesehatan, ekonomi dan sosial. Penelitian ini bertujuan mengetahui hubungan tingkat pengetahuan dan perilaku masyarakat tentang covid-19 di masa pandemi covid-19 di Desa Montong Beter Kecamatan Sakra Barat. Jenis penelitian adalah deskriptif analitik dengan pendekatan Cross-Sectional Study. Jumlah sampel sebanyak 100 responden yang memenuhi kriteria inklusi. Teknik sampling penelitian dengan metode consecutive sampling. Pengambilan data menggunakan kuesioner google form dan disebarkan melalui WhatsApp. Hasil penelitian menunjukkan tingkat pengetahuan masyarakat dalam kategori baik yaitu sebanyak 85 responden (85\%). Perilaku masyarakat Desa Montong Beter di masa pandemi Covid-19 terkait upaya dalam pencegahannya dalam kategori cukup baik yaitu sebesar 54 responden (54\%). Uji gamma diperoleh nilai p 0,005 (sig <0,05) dan koefisien korelasi 0,657 yang menunjukkan bahwa terdapat hubungan yang kuat antara pengetahuan masyarakat dengan perilaku pencegahan Covid19. Simpulan pengetahuan masyarakat dalam kategori baik, sedangkan perilaku masyarakat dalam kategori cukup baik. Terdapat hubungan antara pengetahuan dengan perilaku masyarakat dalam upaya pencegahan Covid-19 di masa pandemi covid-19 di Desa Montong Beter Kecamatan Sakra Barat.
\end{abstract}

\section{Kata kunci : Covid-19, Pengetahuan, Perilaku}

\begin{abstract}
Covid-19 is a respiratory infection disease caused by SARS-CoV-2. The Covid-19 pandemic is considered the most crucial global health disaster of this century and the greatest challenge facing mankind since World War II. The number of cases in Indonesia continues to increase every day and poses a threat to society in terms of health, economy and social. This study aims to determine the relationship between the level of knowledge and community behavior about Covid-19 during the Covid-19 pandemic in Montong Beter Village, West Sakra District. This type of research is descriptive analytic with a Cross-Sectional Study approach. The number of samples is 100 respondents who meet the inclusion criteria. The sampling technique of the study was the consecutive sampling method. Collecting data using a google form questionnaire and distributed via WhatsApp. The results showed that the level of public knowledge was in the good category, as many as 85 respondents (85\%). The behavior of the people of Montong Beter Village during the Covid-19 pandemic related to efforts to prevent it was in the fairly good category, namely 54
\end{abstract}


respondents $(54 \%)$. The gamma test obtained a $\mathrm{p}$ value of $0.005(\mathrm{sig}<0.05)$ and a correlation coefficient of 0.657 which indicates that there is a strong relationship between public knowledge and Covid-19 prevention behavior. The conclusion is that the knowledge of the community is in the good category, while the behavior of the community is in the fairly good category. There is a relationship between knowledge and community behavior in efforts to prevent Covid-19 during the Covid-19 pandemic in Montong Beter Village, West Sakra District.

\section{Keywords: Covid-19, Knowledge, Behaviour}

\section{PENDAHULUAN}

Penyakit coronavirus (Covid-19) akhirnya dinyatakan sebagai pandemi, penyakit yang penyebarannya telah merambah seluruh dunia. Pernyataan WHO tersebut disampaikan oleh Direktur Jenderal Tedros Adhanom Ghebreyesus pada 11 Maret 2020 lalu, ketika 114 negara melaporkan 118.000 pasien positif terjangkit virus korona dan 4.291 di antaranya meninggal dunia sebagian besar di Wuhan, sebuah kota di Provinsi Hubei, China, tempat virus tersebut kali pertama teridentifikasi menginfeksi manusia. Pada 11 Maret 2020 itu, Indonesia yang melaporkan pasien pertamanya pada 2 Maret 2020 baru memasuki hari ke-9 sebagai salah satu negara terjangkit, dengan 34 pasien positif dan belum ada yang meninggal. Hingga akhir Maret 2020, teridentifikasi 1.528 pasien positif Covid-19, dengan 81 di antaranya telah dinyatakan sembuh dan 136 pasien meninggal dunia. Di seluruh dunia, 200 negara melaporkan 789.218 kasus dan lebih dari 37.000 (Pariang et al., 2020).

Provinsi Nusa Tenggara Barat merupakan salah satu provinsi dengan kasus positif terbanyak yakni 11,116 kasus dengan jumlah kematian 481 kasus berdasarkan data Dinas Kesehatan NTB hingga tanggal 4 april 2021. Adanya penularan virus melalui transmisi lokal ini mengakibatkan jumlah kasus positif Covid19 di berbagai kabupaten/kota terus meningkat. Diantaranya kasus di Kabupaten Lombok Timur mencapai 1293 orang, terdiri dari 36 orang masih melakukan isolasi, 1216 orang sembuh dan 41 orang meninggal dunia. Dua hal ini meningkatkan kewaspadaan untuk tiap kabupaten/kota, kecamatan maupun desa untuk melakukan antisipasi, khususnya di Desa Montong Beter Kecamatan Sakra Barat.

Periode mulai peningkatan kasus sampai diawalinya PPKM darurat pada tanggal 4 Juli 2021 sampai tanggal 3 Agustus 2021 terlihat mengalami perburukan level. Tanggal 29 Juni 2021 ada kabupaten/kota yang berada pada level 1 dan tidak ada yang berada pada level 4 . Pada tanggal 6 Juli 2021, tidak ada kabupaten/kota yang berada pada level 1 lagi namun berada pada level 2, 3, dan 4. Perburukan terjadi pada tanggal 27 Juli 2021 dan 3 Agustus dimana kabupaten/kota di NTB berada. Sebagian besar berada pada level 3 dan ada yang berada di level 4 (Kementerian Kesehatan Republik Indonesia, 2021).

Pandemi Covid-19 ini telah mengakibatkan ancaman bagi masyarakat dalam hal kesehatan, ekonomi, dan sosial. Hal ini disebabkan karena penyakit ini diakibatkan oleh virus yang sangat baru sehingga banyak pengetahuan tentang virus baru ini tidak tersedia (Chakraborty and Maity, 2020). Jumlah penderita akibat Covid-19 ini terjadi peningkatan yang signifikan dalam waktu yang sangat cepat sehingga membutuhkan penanganan segera. Virus corona dapat dengan mudah menyebar dan menginfeksi siapapun tanpa memandang usia. Upaya pemutusan rantai penyebaran Covid-19 membutuhkan pemahaman dan pengetahuan yang baik dari seluruh komponen termasuk masyarakat. Pengetahuan tentang penyakit Covid-19 merupakan hal yang sangat penting agar tidak menyebabkan peningkatan jumlah kasus penyakit Covid-19. Pengetahuan pasien Covid- 
19 dapat diartikan sebagai hasil tahu dari pasien mengenai penyakitnya, cara pencegahan, pengobatan dan komplikasinya (Mona, 2020).

Berdasarkan penelitian yang telah dilakukan tentang pengetahuan berhubungan dengan peningkatan perilaku pencegahan Covid-19 bahwa ada hubungan antara pengetahuan responden dengan perilaku pencegahan Covid-19 di masyarakat. Hasil penelitian menunjukkan bahwa pengetahuan responden tentang pencegahan Covid-19 sebagian besar dalam kategori baik yaitu sebanyak 86 responden (82,7\%). Perilaku responden dalam pencegahan Covid-19 sebagian besar dalam kategori cukup yaitu sebanyak 53 responden (51,0\%). Sehingga peningkatan pengetahuan masyarakat diperlukan untuk meningkatkan perilaku pencegahan Covid-19 (Mujiburrahman et al., 2021).

Berdasarkan uraian di atas, peneliti tertarik untuk melakukan penelitian tentang hubungan tingkat pengetahuan dan perilaku masyarakat tentang Covid-19 di masa pandemi Covid-19.

\section{METODE PENELITIAN}

\section{Alat dan Bahan}

Alat yang digunakan dalam penelitian ini berupa kuesioner yang terdiri dari 19 pertanyaan untuk tingkat pengetahuan tentang Covid-19 dan 14 pernyataan untuk perilaku di masa Pandemi Covid-19.

\section{Metode Penelitian}

Jenis penelitian ini adalah deskriptif analitik dengan pendekatan Cross-Sectional Study. Populasi dalam penelitian meliputi masyarakat di Desa Montong Beter Kecamatan Sakra Barat Kabupaten Lombok Timur. Jumlah sampel yang digunakan adalah 100 responden yang memenuhi kriteria inklusi. Teknik sampling dalam penelitian ini menggunakan concecutive sampling.

Kriteria inklusi meliputi: a. Masyarakat Desa Montong Beter Kecamatan Sakra Barat yang berusia 2645 tahun.

b. Memiliki Handphone dan menggunakan Whatsapp.

c. Bersedia menjadi responden.

Kriteria eksklusi meliputi:

a. Responden yang tidak mengisi kuesioner dengan lengkap atau terjadi kesalahan sistem yaitu data yang terduplikasi.

b. Berprofesi sebagai tenaga kesehatan.

Pengumpulan data pada penelitian ini dilakukan dengan menyebarkan kuesioner melalui grup WhatsApp yang dibuat dalam bentuk google form yang terdiri dari informed concent (lembar persetujuan dari responden), karakteristik responden, kuesioner pernyataan tingkat pengetahuan tentang covid-19 dan pernyataan perilaku di masa Pandemi Covid-19. Penelitian ini telah mendapatkan layak etik dari Komisi Etik Penelitian Kesehatan Universitas Negeri Semarang dengan Nomor: 132/KEPK/EC/2021.

Analisis data dalam penelitian ini menggunakan analisis univariat yang ditampilkan dalam tabel distribusi frekuensi dan analisis bivariate dilakukan menggunakan uji gamma.

\section{HASIL DAN PEMBAHASAN}

\section{Hasil Uji Validitas dan Reliabilitas}

Sebelum kuesioner digunakan untuk penelitian, dilakukan uji validitas dan reliabilitas. Uji validitas dilakukan untuk mengetahui kevalidan atau kesesuaian kuesioner yang digunakan, sedangkan uji reliablitas untuk melihat stabilitas dan konsistensi dari kuesioner yang digunakan.

Hasil uji validitas pada penelitian ini dikatakan valid dengan nilai $r$ hitung lebih dari $r$ tabel. Sedangkan hasil uji reliabilitas dinyatakan reliabel untuk variabel tingkat pengetahuan dan perilaku jika alpha cronbach yang didapatkan $\geq 0,60$. 


\section{Karakteristik Responden}

Tabel 1. Karakteristik Responden

\begin{tabular}{ccc}
\hline Karakteristik & $\begin{array}{c}\text { Frekuensi } \\
(\mathrm{n})\end{array}$ & $\begin{array}{c}\text { Persentase } \\
(\%)\end{array}$ \\
\hline Usia (tahun) & & \\
\hline $26-35$ & 62 & 62 \\
\hline $36-45$ & 38 & 38 \\
\hline Jenis Kelamin & & \\
\hline Laki-laki & 49 & 49 \\
\hline Perempuan & 51 & 51 \\
\hline Jenis Pendidikan & & \\
\hline SD & 5 & 5 \\
\hline SMP & 9 & 9 \\
\hline SMA & 22 & 22 \\
\hline DIII & 4 & 4 \\
\hline S1 & 50 & 50 \\
\hline S2 & 10 & 10 \\
\hline Jenis Pekerjaan & & \\
\hline Tidak Bekerja & 21 & 21 \\
\hline Karyawan Swasta & 33 & 33 \\
\hline PNS-ASN & 5 & 5 \\
\hline Lain-lain & 41 & 41 \\
\hline
\end{tabular}

Berdasarkan tabel 1, menunjukkan bahwa sebagian besar responden berada pada rentang usia 26-35 tahun (dewasa awal) yaitu sebanyak 62 responden $(62 \%)$, berjenis kelamin perempuan yaitu sebanyak 51 responden $(51 \%)$. Tingkat pendidikan S1 sebanyak 50 responden (50\%) dan memiliki pekerjaan yang bervariasi dilihat dari persentasi jenis pekerjain lain-lain sebanyak 41 responden $(41 \%)$.

\section{Tingkat Pengetahuan Responden tentang Covid-19}

Tabel 2. Tingkat Pengetahuan Responden

\begin{tabular}{ccc}
\hline $\begin{array}{c}\text { Tingkat } \\
\text { Pengetahuan }\end{array}$ & $\begin{array}{c}\text { Frekuensi } \\
(\mathrm{n})\end{array}$ & $\begin{array}{c}\text { Persentase } \\
(\%)\end{array}$ \\
\hline Baik & 85 & 85 \\
\hline Cukup & 15 & 15 \\
\hline Kurang & 0 & 0 \\
\hline Total & 100 & 100 \\
\hline
\end{tabular}

Berdasarkan tabel 2 tingkat pengetahuan sebagian besar responden dalam kategori baik yaitu sebanyak 85 responden (85\%). Pengetahuan masyarakat tentang Covid-19 merupakan aspek yang sangat penting dalam masa pandemi seperti sekarang ini, yang meliputi penyebab Covid19, tanda dan gejala, pemeriksaan yang diperlukan dan proses transmisi serta upaya dalam pencegahan Covid-19. Pengetahuan masyarakat Desa Montong Beter yang baik tentang Covid-19 berpengaruh terhadap kejadian dan pencegahan Covid-19.

Hasil penelitian ini sejalan dengan penelitian yang dilakukan oleh (Yanti et al., 2020) yang menunjukkan bahwa 99\% masyarakat Indonesia memiliki pengetahuan yang baik, 59\% memiliki sikap yang positif dan $93 \%$ masyarakat memiliki perilaku yang baik terhadap upaya pencegahan Covid-19 di Indonesia.

Seseorang yang telah mengetahui tentang suatu informasi tertentu, maka dia akan mampu menentukan dan mengambil keputusan bagaimana dia harus mangambil sikap atau tindakan. Dengan kata lain, saat seseorang mempunyai informasi tentang Covid-19, maka ia akan mampu untuk menentukan bagaimana dirinya harus berperilaku terhadap Covid-19 tersebut (Achmadi, 2014).

Berdasarkan tabel 3, terdapat 5 item pernyataan dengan frekuensi salah paling banyak saat dijawab oleh masyarakat Desa Montong Beter yaitu pada item pernyataan no $4,7,8$, 9, dan 14 . Pada item pernyataan nomor 4, virus corona paling banyak menyerang saluran perncernaan menunjukkan hasil sebanyak 48 responden (48\%) dari 100 responden yang menjawab salah, yang dalam faktanya virus corona paling banyak menyerang saluran pernafasan. 
Tabel 3. Distribusi Kuesioner Tingkat Pengetahuan

\begin{tabular}{|c|c|c|c|}
\hline \multirow[t]{2}{*}{ No } & \multirow[t]{2}{*}{ Pernyataan } & \multicolumn{2}{|c|}{ Jawaban } \\
\hline & & $\mathrm{B}$ & $\mathrm{S}$ \\
\hline 1 & $\begin{array}{l}\text { Covid } 19 \text { adalah nama } \\
\text { penyakit yang disebabkan } \\
\text { oleh virus corona (SARS } \\
\text { CoV-2) }\end{array}$ & $\begin{array}{c}95 \\
(95 \%)\end{array}$ & $\begin{array}{c}5 \\
(5 \%)\end{array}$ \\
\hline 2 & $\begin{array}{l}\text { Penyebaran virus corona } \\
\text { pertama kali dilaporkan dari } \\
\text { Wuhan China pada bulan } \\
\text { Desember } 2019\end{array}$ & $\begin{array}{c}97 \\
(97 \%)\end{array}$ & $\begin{array}{c}3 \\
(3 \%)\end{array}$ \\
\hline 3 & $\begin{array}{l}\text { Waktu antara terpapar virus } \\
\text { corona dan menunjukkan } \\
\text { gejala awal adalah } 1-14 \text { hari }\end{array}$ & $\begin{array}{c}95 \\
(95 \%)\end{array}$ & $\begin{array}{c}5 \\
(5 \%\end{array}$ \\
\hline 4 & $\begin{array}{lll}\text { Virus corona paling } & \text { banyak } \\
\text { menyerang } & \text { saluran } \\
\text { perncernaan } & \\
\end{array}$ & $\begin{array}{c}52 \\
(52 \%)\end{array}$ & $\begin{array}{c}48 \\
(48 \% \\
)\end{array}$ \\
\hline 5 & $\begin{array}{l}\text { Menutup hidung dan mulut } \\
\text { menggunakan lipatan siku } \\
\text { merupakan etika pada saat } \\
\text { batuk ataupun bersin }\end{array}$ & $\begin{array}{c}79 \\
(79 \%)\end{array}$ & $\begin{array}{c}21 \\
(21 \% \\
\quad)\end{array}$ \\
\hline 6 & $\begin{array}{l}\text { Gejala pasien dengan covid } \\
19 \text { yang berat adalah demam } \\
\text { tinggi, batuk dan sesak napas }\end{array}$ & $\begin{array}{c}96 \\
(96 \%)\end{array}$ & $\begin{array}{c}4 \\
(4 \%)\end{array}$ \\
\hline 7 & $\begin{array}{l}\text { Pasien terdiagnosa covid } 19 \\
\text { dapat tidak menunjukkan } \\
\text { gejala apapun }\end{array}$ & $\begin{array}{c}72 \\
(72 \%)\end{array}$ & $\begin{array}{c}28 \\
(28 \% \\
)\end{array}$ \\
\hline 8 & $\begin{array}{l}\text { Orang yang bisa menularkan } \\
\text { Covid-19 hanya orang yang } \\
\text { memiliki gejala. }\end{array}$ & $\begin{array}{c}51 \\
(51 \%)\end{array}$ & $\begin{array}{l}49 \\
(49 \% \\
)\end{array}$ \\
\hline 9 & $\begin{array}{l}\text { Virus Corona tidak akan } \\
\text { menular pada saat orang } \\
\text { berbicara }\end{array}$ & $\begin{array}{c}65 \\
(65 \%)\end{array}$ & $\begin{array}{l}35 \\
(35 \% \\
)\end{array}$ \\
\hline 10 & $\begin{array}{l}\text { Polymerase Chain Reaction } \\
\text { (PCR) covid } 19 \text { adalah tes } \\
\text { dengan melakukan swab } \\
\text { saluran nafas untuk } \\
\text { memastikan penyakit Covid- } \\
19\end{array}$ & $\begin{array}{c}97 \\
(97 \%)\end{array}$ & $\begin{array}{l}3 \\
(3 \%)\end{array}$ \\
\hline 11 & $\begin{array}{l}\text { Penularan virus corona adalah } \\
\text { melalui udara bebas sehingga } \\
\text { masyarakat dihimbau } \\
\text { menggunakan masker. }\end{array}$ & $\begin{array}{c}85 \\
(85 \%)\end{array}$ & $\begin{array}{l}15 \\
(15 \% \\
)\end{array}$ \\
\hline 12 & $\begin{array}{l}\text { Cuci tangan menggunakan } \\
\text { sabun adalah salah satu cara } \\
\text { mencegah penularan virus } \\
\text { corona. }\end{array}$ & $\begin{array}{c}100 \\
(100 \%)\end{array}$ & $\begin{array}{l}0 \\
(0 \%)\end{array}$ \\
\hline 13 & $\begin{array}{l}\text { Jarak aman untuk } \\
\text { berkomunikasi langsung pada } \\
\text { masa pandemi covid } 19 \\
\text { adalah } 1-1,5 \text { meter. }\end{array}$ & $\begin{array}{c}96 \\
(96 \%)\end{array}$ & $\begin{array}{l}4 \\
(4 \%)\end{array}$ \\
\hline 14 & Orang yang sehat tidak perlu & 76 & 24 \\
\hline
\end{tabular}

\begin{tabular}{|c|c|c|c|}
\hline & $\begin{array}{l}\text { menggunakan masker saat } \\
\text { pergi keluar rumah }\end{array}$ & & ) \\
\hline 15 & $\begin{array}{l}\text { Vaksin untuk pencegahan } \\
\text { Covid-19 diberikan sebanyak } \\
2 \text { tahap. }\end{array}$ & $\begin{array}{c}92 \\
(92 \%)\end{array}$ & $\begin{array}{l}8 \\
(8 \%)\end{array}$ \\
\hline 16 & $\begin{array}{l}\text { Risiko kematian pasien } \\
\text { COVID-19 lebih tinggi pada } \\
\text { penderita yang memiliki } \\
\text { penyakit kronis }\end{array}$ & $\begin{array}{c}90 \\
(90 \%)\end{array}$ & $\begin{array}{l}10 \\
(10\end{array}$ \\
\hline 17 & $\begin{array}{l}\text { Cara memakai masker yang } \\
\text { benar adalah menutupi daerah } \\
\text { hidung sampai dagu dan } \\
\text { pastikan tidak ada celah } \\
\text { antara masker dengan wajah. }\end{array}$ & $\begin{array}{c}100 \\
(100 \%)\end{array}$ & $\begin{array}{l}0 \\
(0 \%\end{array}$ \\
\hline 18 & $\begin{array}{l}\text { Sebelum memakai masker } \\
\text { dan setelah melepas masker } \\
\text { harus mencuci tangan. }\end{array}$ & $\begin{array}{c}97 \\
(97 \%)\end{array}$ & $\begin{array}{l}3 \\
(3 \%\end{array}$ \\
\hline 19 & $\begin{array}{l}\text { Mengkonsumsi suplemen } \\
\text { kesehatan seperti vitamin C, } \\
\mathrm{D} \text {, E, zinc dan selenium dapat } \\
\text { berguna untuk memeliharan } \\
\text { daya tahan tubuh dalam } \\
\text { menghadapi covid-19. }\end{array}$ & $\begin{array}{c}100 \\
(100 \%)\end{array}$ & $\begin{array}{l}0 \\
(0 \%\end{array}$ \\
\hline
\end{tabular}

Keterangan :

Jawaban Salah (S) $\quad: 4,8,9,14$

Jawaban Benar (B) : : 1, 2, 3, 5, 6, 7, 10, 11, 12, 13,

$16,17,18,19$

Pada item pernyataan nomor 7, sebanyak 28 responden (28\%) menjawab salah untuk pernyataan pasien terdiagnosa Covid-19 dapat tidak menunjukkan gejala apapun. Pada item pernyataan nomor 8 dengan pernyataan orang yang bisa menularkan Covid-19 hanya orang yang memiliki gejala. Dalam faktanya orang dengan tanpa gejala memiliki kecenderungan mampu menularkan virus SARS-CoV-2 sebanding dengan orang dengan berbagai gejala yang ditunjukkan. Orang yang tampaknya tidak memiliki gejala tetap memiliki potensi adanya riwayat paparan dari orang positif Covid-19. Kelompok orang yang tanpa gejala secara umum memiliki masa inkubasi virus yang jauh lebih pendek, sehingga gejala yang ditimbulkan secara garis besar tidak akan terlihat, dan mayoritas kelompok ini merupakan orang-orang pada usia muda dibandingkan orang pada usia tua (Huang et 
al., 2020). Oleh karena itu, masyarakat harus lebih menyadari adanya orang tanpa gejala, serta selalu memiliki pengetahuan yang baik terkait pandemi Covid-19 untuk mencegah adanya penularan.

Pada item pernyataan nomor 9 dengan pernyataan virus corona tidak akan menular pada saat orang berbicara sebanyak 35 responden (35\%) menjawab salah dan pada item nomor 14 dengan pernyataan orang yang sehat tidak perlu menggunakan masker saat pergi ke luar rumah. Dalam faktanya penularan SARS-CoV-2 dari pasien bergejala (simptomatik) terjadi melalui droplet yang dikeluarkan saat batuk atau bersin (Han and Yang, 2020). Sehingga penggunaan masker sangat diperlukan untuk mencegah terjadinya penularan Covid-19.

Edukasi sangat diperlukan untuk memperbaiki persepsi masyarakat yang masih kurang tepat. Pendidikan professional berkelanjutan diperlukan untuk meningkatkan pengetahuan dan mengubah sikap negatif serta meningkatkan praktik pencegahan dan pengobatan (Olum et al., 2020).

\section{Perilaku Responden di masa Pandemi Covid-19}

Tabel 4. Perilaku Responden di masa Pandemi Covid-19

\begin{tabular}{ccc}
\hline Perilaku & Frekuensi (n) & Persentase (\%) \\
\hline Baik & 24 & 24 \\
\hline Cukup & 54 & 54 \\
\hline Kurang & 22 & 22 \\
\hline Total & 100 & 100 \\
\hline
\end{tabular}

Tabel 4 menunjukkan bahwa perilaku sebagian besar responden dalam upaya pencegahan Covid-19 berada dalam kategori cukup yaitu sebanyak 54 responden (54\%). Perilaku kesehatan dipengaruhi oleh banyak faktor, diantaranya pengetahuan, persepsi, emosi, motivasi dan lingkungan (Rahayu et al., 2014).

Dalam penelitian ini menunjukkan perilaku yang dilakukan responden di masa pandemi Covid-19 sebagian besar pada kategori cukup baik yaitu sebanyak 54 reponden (54\%), responden yang berperilaku baik sebanyak 24 responden (24\%) dan yang berperilaku kurang baik sebanyak 22 responden (22\%). Berdasarkan hasil penelitian, terdapat 6 item pernyataan dengan frekuensi menjawab "tidak pernah" paling banyak yaitu perilaku masyarakat terkait penggunaan hand sanitizer jika air dan sabun tidak tersedia, perilaku masyarakat terkait mencuci tangan dengan sabun sebelum masuk rumah, toko/minimarket, ATM dan fasilitas lainnya, perilaku masyarakat dalam melakukan desinfeksi pada benda dan barang di rumah yang sering disentuh, perilaku masyarakat terkait mengingatkan orang lain yang tidak menggunakan masker saat berada di luar rumah, perilaku masyarakat terkait memanfaatkan online shop dan delivery untuk memenuhi kebutuhan dan perilaku masyarakat terkait mengkonsumsi suplemen kesehatan salah satunya seperti vitamin $C$, D, E, zinc maupun selenium untuk memelihara daya tahan tubuh dalam menghadapi Covid-19.

Pada item pernyataan tentang perilaku masyarakat terkait penggunaan hand sanitizer jika air dan sabun tidak tersedia dengan responden yang menjawab tidak pernah yaitu 30 responden (30\%). Pada penelitian ini sebagian masyarakat sudah berupaya melakukan pencegahan dengan menggunakan hand sanitizer jika air dan sabun tidak tersedia. Namun masih banyak masyarakat yang tidak melakukan anjuran tersebut dikarenakan kurangnya ketersediaan hand sanitizer di tempat umum. Antiseptik merupakan bahan kimia untuk mencegah multiplikasi mikroorganisme pada permukaan tubuh, dengan cara membunuh mikroorganisme tersebut atau menghambat pertumbuhan dan aktivitas metaboliknya. Hand sanitizer antiseptik yang sering 
digunakan adalah alkohol (Desiyanto and Djannah, 2013).

Pada item pernyataan tentang perilaku masyarakat terkait mencuci tangan dengan sabun sebelum masuk rumah, toko/minimarket, ATM dan fasilitas lainnya dengan responden yang menjawab tidak pernah yaitu 29 responden (29\%). Pada penelitian ini sebagian masyarakat sudah berupaya melakukan pencegahan dengan mencuci tangan dengan sabun sebelum masuk rumah, toko/minimarket, ATM dan fasilitas lainnya. Namun masih banyak masyarakat yang kurang disiplin dan tidak melakukan anjuran tersebut. Hal ini dikarenakan kurangnya edukasi pemerintah pada masyarakat dan kurangnya ketersediaan fasilitas tempat cuci tangan di tempat umum. Mencuci tangan adalah salah satu upaya yang efektif untuk membunuh kuman, diketahui bahwa virus Covid-19 dapat menempel pada bagian tubuh terutama tangan saat menyentuh benda yang sudah tertular oleh droplet.

Pada mereka yang telah terinfeksi, virus Covid-19 terkonsentrasi di lapisan lendir hidung dan mulut. Percikan dari saluran pernapasan ketika bersin, batuk, atau bicara dapat menyebarkan virus tersebut ke orangorang di sekitarnya. Menjaga jarak hingga lebih dari 1 meter dan sebaiknya minimal 2 meter, bila berhadap-hadapan dengan orang lain dapat bantu mencegah penularan. Bagi yang merasa tidak sehat adalah wajib menggunakan masker agar tidak menularkan penyakit ke orang lain (Pariang et al., 2020).

Pada item pernyataan tentang perilaku masyarakat dalam melakukan desinfeksi pada benda dan barang di rumah yang sering disentuh dengan responden yang menjawab tidak pernah yaitu 38 responden (38\%). Hal ini dapat dikarenakan kurangnya pengetahuan masyarakat. Virus Covid-19 diketahui dapat bertahan cukup lama pada permukaan plastik maupun baja (sampai 3 hari) dan permukaan cardboard (1 hari). Termasuk dalam kategori "plastik dan baja" adalah tombol lift, pintu dan pegangan untuk naik dan berdiri di alat transportasi umum, uang logam (terutama yang tidak mengandung tembaga), pegangan pintu, dan sebagainya. Sementara itu, contoh cardboard bukan hanya karton, melainkan juga kertas, termasuk uang kertas. Sebab itu, dianjurkan bagi kita semua untuk sering cuci tangan dengan sabun selama setidaknya 20 detik dan menghindari menyentuh hidung, mulut, dan mata (Pariang et al., 2020). Menurut penelitian (Kampf et al., 2020) bahwa virus corona dapat bertahan hidup dan menetap pada permukaan suatu benda selama 9 hari dengan kondisi suhu kamar.

Pada item pernyataan tentang perilaku masyarakat terkait mengingatkan orang lain yang tidak menggunakan masker saat berada di luar rumah dengan responden yang menjawab tidak pernah yaitu 29 responden (29\%). Hal ini dikarenakan kurangnya kepedulian masyarakat terhadap sekitar.

Pada item pernyataan tentang perilaku masyarakat terkait memanfaatkan online shop dan delivery untuk memenuhi kebutuhan dengan responden yang menjawab tidak pernah yaitu 20 responden (20\%). Karakteristik masyarakat di desa yang jauh dari perkotaan, dan kurangnya sarana dan prasarana untuk memanfaatkan online shop dan delivery untuk memenuhi kebutuhan sehari-hari seperti belum tersedia gojek, grabfood dan lain sebagainya kurang optimal.

Pada item pernyataan tentang perilaku masyarakat terkait mengkonsumsi suplemen kesehatan salah satunya seperti vitamin $C$, D, E, zinc maupun selenium untuk memelihara daya tahan tubuh dalam menghadapi Covid-19 dengan responden yang menjawab tidak pernah yaitu 27 responden (27\%). Pada penelitian ini kurangnya pengetahuan masyarakat tentang kegunaan suplemen tersebut untuk 
memelihara daya tahan tubuh dalam menghadapi Covid-19. Selain itu karena kurangnya ketetersediaan suplemen di tengah-tengah masyarakat.

Kepatuhan merupakan perilaku yang baik dari masyarakat. Sebaliknya perilaku masyarakat yang tidak baik akan meningkatkan jumlah kasus dan angka kematian akibat penularan Covid-19 (Simbolon et al., 2020). Oleh karena itu pengetahuan masyarakat yang masih perlu diluruskan dan perilaku masyarakat yang masih negatif dapat diupayakan dengan kegiatan pembelajaran melalui edukasi oleh pihak-pihak yang berwenang. Dalam masyarakat, forum kesehatan desa atau sejenisnya dapat mengambil peran dalam upaya pelaksanaan kegiatan yang dimaksud.

5. Hubungan Tingkat Pengetahuan dengan Perilaku Masyarakat di masa Pandemi Covid-19

Tabel 5. Hasil Uji Gamma Hubungan Tingkat Pengetahuan dan Perilaku dalam Upaya Pencegahan Covid-19

\begin{tabular}{cccccc}
\hline Tingkat & \multicolumn{3}{c}{ Perilaku } & Koefi & Nilai \\
\cline { 2 - 4 } Pengetahuan & Baik & Cukup & Kurang & $\begin{array}{c}\text { Sien } \\
\text { Korel } \\
\text { asi }\end{array}$ & \\
\hline Baik & 23 & 48 & 14 & 0,657 & 0,005 \\
\hline Cukup & 1 & 6 & 8 & & \\
\hline
\end{tabular}

Tabel 5 menunjukkan bahwa responden dengan pengetahuan yang baik dan perilaku yang baik sebanyak 23 responden (23\%), pengetahuan yang baik dan perilaku cukup 48 responden (48\%), pengetahuan baik dan perilaku kurang 14 responden (14\%), pengetahuan cukup dan perilaku baik 1 responden (1\%), pengetahuan cukup dan perilaku cukup 6 responden $(6 \%)$, pengetahuan cukup dan perilaku kurang 8 responden $(8 \%)$.

Berdasarkan hasil uji gamma diperoleh nilai $\mathrm{p}=0,005 \quad(\mathrm{sig}<0,05)$. Hal ini menunjukkan bahwa terdapat hubungan yang signifikan antara tingkat pengetahuan dengan perilaku masyarakat di masa pandemi Covid19 dalam upaya pencegahannya. Hasil koefisien korelasi 0,657 termasuk dalam range $0,51-0,75$ yang dapat dinyatakan bahwa koefisien korelasi memiliki tingkat kekuatan hubungan yang kuat. Berdasarkan hasil nilai $p$ dan koesfisien korelasi menunjukkan bahwa ada hubungan yang kuat antara tingkat pengetahuan dan perilaku masyarakat di masa pandemi Covid-19 dalam upaya pencegahannya. Penelitian lain menunjukkan hasil bahwa ada hubungan antara pengetahuan responden dengan perilaku pencegahan Covid-19 di masyarakat (Mujiburrahman et al., 2021).

Peneliti berasumsi bahwa pengetahuan sangat menentukan setiap individu sehingga akan mempengaruhi perilaku atau kebiasaan dalam kehidupan sehari-hari, dan akan meningkatkan kesadaran masyarakat dalam upaya pencegahan Covid-19. Karena semakin tinggi tingkat pengetahuan seseorang maka semakin mudah untuk menentukan apa yang harus ia pilih dan apa yang harus ia lakukan dalam kehidupannya. Tingkat pengetahuan yang tinggi juga didukung dengan tingkat pendidikan, tingkat pendidikan seseorang yang tinggi akan semakin mudah untuk mendapatkan akses informasi tentang suatu permasalahan (Yanti et al., 2020).

\section{SIMPULAN}

Terdapat hubungan yang kuat antara tingkat pengetahuan dengan perilaku masyarakat di masa Pandemi Covid-19 dalam upaya pencegahannya dengan nilai p 0,005 dan koefisien korelasi 0,657.

\section{DAFTAR PUSTAKA}

Achmadi, U.F., 2014. Kesehatan dan Masyarakat Teori dan Aplikasi, First Edit. ed. RajaGrafindo Persada, Jakarta.

Chakraborty, I., Maity, P., 2020. COVID-19 outbreak: Migration, effects on society, 
global environment and prevention. Sci. Total Environ. 728, 138882. https://doi.org/10.1016/j.scitotenv.2020.13 8882

Desiyanto, F.A., Djannah, S.N., 2013. Efektivitas Mencuci Tangan Menggunakan Cairan Pembersih Tangan Antiseptik (Hand Sanitizer) Terhadap Jumlah Angka Kuman. J. Kesehat. Masy. (Journal Public Heal. 7, 75-82. https://doi.org/10.12928/kesmas.v7i2.1041

Han, Y., Yang, H., 2020. The transmission and diagnosis of 2019 novel coronavirus infection disease (COVID-19): A Chinese perspective. J. Med. Virol. 92, 639-644. https://doi.org/10.1002/jmv.25749

Huang, C., Wang, Y., Li, X., Ren, L., Zhao, J., Hu, Y., Zhang, L., Fan, G., Xu, J., Gu, X., Cheng, Z., Yu, T., Xia, J., Wei, Y., Wu, W., Xie, X., Yin, W., Li, H., Liu, M., Xiao, Y., Gao, H., Guo, L., Xie, J., Wang, G., Jiang, R., Gao, Z., Jin, Q., Wang, J., Cao, B., 2020. Clinical features of patients infected with 2019 novel coronavirus in Wuhan, China. Lancet 395, 497-506. https://doi.org/10.1016/S0140-

6736(20)30183-5

Kampf, G., Todt, D., Pfaender, S., Steinmann, E., 2020. Persistence of coronaviruses on inanimate surfaces and their inactivation with biocidal agents. J. Hosp. Infect. 104, 246-251.

https://doi.org/10.1016/j.jhin.2020.01.022

Kementerian Kesehatan Republik Indonesia, 2021. Level Situasi Covid-19. Kementerian Kesehatan Republik Indonesia.

Mona, N., 2020. Konsep Isolasi Dalam Jaringan Sosial Untuk Meminimalisasi Efek Contagious (Kasus Penyebaran Virus Corona Di Indonesia). J. Sos. Hum. Terap. 2, $117-125$. https://doi.org/10.7454/jsht.v2i2.86

Mujiburrahman, Riyadi, M.E., Ningsih, M.U., 2021. Pengetahuan Berhubungan dengan Peningkatan Perilaku Pencegahan COVID-
19 di Masyarakat. J. Keperawatan Terpadu 2, 130-140.

Olum, R., Chekwech, G., Wekha, G., Nassozi, D.R., Bongomin, F., 2020. Coronavirus Disease-2019: Knowledge, Attitude, and Practices of Health Care Workers at Makerere University Teaching Hospitals, Uganda. Front. Public Heal. 8, 1-9. https://doi.org/10.3389/fpubh.2020.00181

Pariang, N.F.., Wijaya, E., Sarnianto, P., Ikawati, Z., Andrajati, R., Puspitasari, I., Noviani, L., 2020. Panduan Praktis Untuk Apoteker. Pengurus Pus. Ikat. Apot. Indones. 53, 1779-1791.

Rahayu, C., Widiati, S., Widyanti, N., 2014. Hubungan antara Pengetahuan, Sikap, dan Perilaku terhadap Pemeliharaan Kebersihan Gigi dan Mulut dengan Status Kesehatan Periodontal Pra Lansia di Posbindu Kecamatan Indihiang Kota Tasikmalaya 21. https://doi.org/https://doi.org/10.22146/maj kedgiind.8515

Simbolon, D., Darwis, Wijaya, A.S., Hermansyah, Andriani, L., Andeka, W., Gazali, M., Muslim, Z., 2020. Compliance of the Academic Civities of the Health Ministry of. Http://Sinta.Ristekbrin.Go.Id/Covid/Penelit ian/Detail/403.

Yanti, B., Wahyudi, E., Wahiduddin, W., Novika, R.G.H., Arina, Y.M.D., Martani, N.S., Nawan, N., 2020. Community Knowledge, Attitudes, and Behavior Towards Social Distancing Policy As Prevention Transmission of Covid-19 in Indonesia. J. Adm. Kesehat. Indones. 8, 4. https://doi.org/10.20473/jaki.v8i2.2020.414 